\title{
Correction: Role of Macrophage Migration Inhibitory Factor (MIF) in Pollen-Induced Allergic Conjunctivitis and Pollen Dermatitis in Mice
}

\section{The PLOS ONE Staff}

The fifth author's name is spelled incorrectly. The correct name is: Nobuyoshi Kitaichi.

The correct citation is: Nagata Y, Yoshihisa Y, Matsunaga K, Rehman MU, Kitaichi N, Shimizu T. (2015) Role of Macrophage Migration Inhibitory Factor (MIF) in Pollen-Induced Allergic Conjunctivitis and Pollen Dermatitis in Mice. PLoS ONE 10(2): e0115593. doi:10.1371/journal.pone.0115593.

\section{Reference}

1. Nagata Y, Yoshihisa Y, Matsunaga K, Rehman MU, Kitaichi N, Shimizu T. (2015) Role of Macrophage Migration Inhibitory Factor (MIF) in Pollen-Induced Allergic Conjunctivitis and Pollen Dermatitis in Mice. PLoS ONE 10(2): e0115593. doi: 10.1371/journal.pone.0115593 PMID: 25647395

\section{open ACCESS}

Citation: The PLOS ONE Staff (2015) Correction: Role of Macrophage Migration Inhibitory Factor (MIF) in Pollen-Induced Allergic Conjunctivitis and Pollen Dermatitis in Mice. PLOS ONE 10(3): e0122546. doi:10.1371/journal.pone.0122546

Published: March 19, 2015

Copyright: @ 2015 The PLOS ONE Staff. This is an open access article distributed under the terms of the Creative Commons Attribution License, which permits unrestricted use, distribution, and reproduction in any medium, provided the original author and source are credited. 